\title{
Front Matter: Volume 6609
}

, "Front Matter: Volume 6609," Proc. SPIE 6609, 15th Czech-Polish-Slovak Conference on Wave and Quantum Aspects of Contemporary Optics, 660901 (21 April 2009); doi: 10.1117/12.741930

SDIE Event: 15th Czech-Polish-Slovak Conference on Wave and Quantum Aspects of Contemporary Optics, 2006, Liberec, Czech Republic 


\title{
PROCEEDINGS OF SPIE
}

\section{5th Czech-Polish-Slovak Conference on \\ Wave and Quantum Aspects of Contemporary Optics}

\author{
Miroslav Miler \\ Dagmar Senderáková \\ Miroslav Hrabovský \\ Editors
}

11-15 September 2006

Liberec, Czech Republic

Organized by

Czech and Slovak Society for Photonics (Czech Republic)

Faculty of Mechanical Engineering, Technical University of Liberec (Czech Republic)

Agency Action M (Czech Republic)

In Cooperation With

SPIE Czech and Slovak Chapter

Palacky University, Faculty of Natural Sciences (Czech Republic)

Published by

SPIE-The International Society for Optical Engineering

Volume 6609

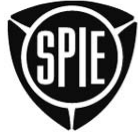

The International Society

for Optical Engineering

Proceedings of SPIE-The International Society for Optical Engineering, 9780819467485, v. 6609

SPIE is an international technical society dedicated to advancing engineering and scientific applications of optical, photonic, imaging, electronic, and optoelectronic technologies. 
The papers included in this volume were part of the technical conference cited on the cover and title page. Papers were selected and subject to review by the editors and conference program committee. Some conference presentations may not be available for publication. The papers published in these proceedings reflect the work and thoughts of the authors and are published herein as submitted. The publisher is not responsible for the validity of the information or for any outcomes resulting from reliance thereon.

Please use the following format to cite material from this book:

Author(s), "Title of Paper," in 15th Czech-Polish-Slovak Conference on Wave and Quantum Aspects of Contemporary Optics, edited by Miroslav Miler, Dagmar Senderáková, Miroslav Hrabovský, Proceedings of SPIE Vol. 6609 (SPIE, Bellingham, WA, 2007) Article CID Number.

ISSN 0277-786X

ISBN 9780819467485

Published by

SPIE-The International Society for Optical Engineering

P.O. Box 10, Bellingham, Washington 98227-0010 USA

Telephone 1 360/676-3290 (Pacific Time) · Fax 1 360/647-1445

http://www.spie.org

Copyright (C) 2007, The Society of Photo-Optical Instrumentation Engineers

Copying of material in this book for internal or personal use, or for the internal or personal use of specific clients, beyond the fair use provisions granted by the U.S. Copyright Law is authorized by SPIE subject to payment of copying fees. The Transactional Reporting Service base fee for this volume is $\$ 18.00$ per article (or portion thereof), which should be paid directly to the Copyright Clearance Center (CCC), 222 Rosewood Drive, Danvers, MA 01923. Payment may also be made electronically through CCC Online at http://www.copyright.com. Other copying for republication, resale, advertising or promotion, or any form of systematic or multiple reproduction of any material in this book is prohibited except with permission in writing from the publisher. The CCC fee code is 0277 $786 \times / 07 / \$ 18.00$

Printed in the United States of America. 


\title{
Contents
}

\author{
xi Conference Committees \\ xiii Introduction \\ xv Conference Pictures
}

\section{INVITED PAPERS}

660902 How to use laser radiative and evanescent interference fields to control movement of the sub-micron objects [6609-01]

P. Zemánek, T. Čižmár, M. Šiler, Institute of Scientific Instruments (Czech Republic); V. Garcés-Chávez, K. Dholakia, Univ. of St. Andrews (United Kingdom); V. Kollárová, Z. Bouchal, Palacky Univ. (Czech Republic)

660903 Optics of nanogratings [6609-02]

M. Foldyna, Technical Univ. Ostrava (Czech Republic) and École Polytechnique (France); K. Postava, Technical Univ. Ostrava (Czech Republic) and Shizuoka Univ. (Japan); R. Ossikovski, A. De Martino, E. Garcia-Caurel, B. Drevillon, École Polytechnique (France); J. Pištora, Technical Univ. of Ostrava (Czech Republic); T. Yamaguchi, Shizuoka Univ. (Japan)

660904 How optics has changed data communications [6609-03]

I. Glesk, Comenius Univ. (Slovak Republic) and Princeton Univ. (USA); P. R. Prucnal, Princeton Univ. (USA)

660905 Cavity ring down and vacuum UV spectroscopy: applications for radical absolute density measurements in plasma [6609-04]

P. Veis, Comenius Univ. (Slovak Republic) and Univ. des Sciences et Technologies de Lille (France); P. Macko, Comenius Univ. (Slovak Republic) and Univ. Libre de Bruxelles (Belgium); J. Jašik, Comenius Univ. (Slovak Republic)

Pagination: Proceedings of SPIE follow an e-First publication model, with papers published first online and then in print and on CD-ROM. Papers are published as they are submitted and meet publication criteria. A unique, consistent, permanent citation identifier (CID) number is assigned to each article at the time of the first publication. Utilization of CIDs allows articles to be fully citable as soon they are published online, and connects the same identifier to all online, print, and electronic versions of the publication.

SPIE uses a six-digit CID article numbering system in which:

- The first four digits correspond to the SPIE volume number.

- The last two digits indicate publication order within the volume using a Base 36 numbering system employing both numerals and letters. These two-number sets start with 00, 01, 02, 03, 04, 05, 06, 07, 08, 09, OA, OB ... OZ, followed by 10-12, 20-2Z, etc.

The CID number appears on each page of the manuscript. The complete citation is used on the first page, and an abbreviated version on subsequent pages. 
660906 The photorefractive effect in LiNbO 3 crystals [6609-05]

I. Turek, N. Tarjányi, Univ. of Žilina (Slovak Republic)

\section{WAVE OPTICS}

660907 Orbital angular momentum of mixed vortex beams [6609-06]

Z. Bouchal, V. Kollárová, Palacký Univ. (Czech Republic); P. Zemánek,

T. Čižmár, Institute of Scientific Instruments (Czech Republic)

660908 Characteristic matrix of anisotropic coupling gap [6609-07]

J. Pištora, J. Vlček, Technical Univ. of Ostrava (Czech Republic); R. Antoš, RIKEN (Japan); T. Yamaguchi, Shizuoka Univ. (Japan); K. Postava, O. Bárta, Technical Univ. of Ostrava (Czech Republic)

660909 What is it optical binding and how to study this phenomena [6609-08]

V. Karásek, P. Zemánek, Institute of Scientific Instruments (Czech Republic)

66090A Reconstruction of the wave tilt and orientation of tilt axis using OVI [6609-09]

M. Borwińska, A. Popiołek-Masajada, B. Dubik, Wrocław Univ. of Technology (Poland)

66090B Design and testing of the phase mask for transfer of information by vortex beams [6609-10]

R. Čelechovský, Z. Bouchal, Palacký Univ. (Czech Republic)

66090C Two generation modes of a laser diode module [6609-11]

D. Senderáková, A. Štrba, V. Mesároš, Comenius Univ. at Bratislava (Slovak Republic)

66090D Axial diffraction patterns in the vicinity of the focus of the off-axis holographic diffractive collimator [6609-12]

M. Hradil, M. Miler, J. Pala, Institute of Radio Engineering and Electronics (Czech Republic)

\section{GUIDED WAVE OPTICS}

66090E Polarizing photonic crystal fibers for different operation range [6609-13] G. Statkiewicz, M. Szpulak, T. Martynkien, W. Urbanczyk, Wroclaw Univ. of Technology (Poland); J. Wojcik, M. Makara, P. Mergo, M. Curie-Skłodowska Univ. (Poland); T. Nasilowski, Vrije Univ. Brussel (Belgium); F. Berghmans, Vrije Univ. Brussel (Belgium) and SCK-CEN (Belgium); H. Thienpont, Vrije Univ. Brussel (Belgium)

66090F Optical gain in planar waveguides [6609-14]

T. Ostatnický, P. Janda, J. Valenta, Charles Univ. in Prague (Czech Republic);

I. Pelant, Institute of Physics (Czech Republic) 
$66090 \mathrm{G}$ Adaptively controlled supercontinuum generation in a microstructure fiber [6609-15]

D. Lorenc, International Laser Ctr. (Slovak Republic) and Comenius Univ. (Slovak Republic); D. Velic, F. Uherek, International Laser Ctr. (Slovak Republic); A. N. Markevitch, R. J. Levis, Temple Univ. (USA)

$66090 \mathrm{H}$ Dispersion measurements of anisotropic materials and a new fiber-optic sensor configuration [6609-16]

R. Chlebus, P. Hlubina, D. Ciprian, Technical Univ. Ostrava (Czech Republic)

66090I Intermodal interference in photonic crystal fibers [6609-17]

I. Turek, D. Káčik, Univ. of Zilina (Slovak Republic); J. Canning, Univ. of Sydney (Australia); I. Martinček, Univ. of Zilina (Slovak Republic); N. Issa, Univ. of Sydney (Australia)

66090J Manufacturing of extremely narrow polymer fibers by non-diffracting beams [6609-18]

J. Ježek, T. Čižmár, P. Zemánek, Institute of Scientific Instruments (Czech

Republic)

66090K Workplace for manufacturing devices based on optical fiber tapers [6609-19] T. Martan, P. Honzátko, J. Kaňka, Institute of Radio Engineering and Electronics (Czech Republic); K. Novotný, Czech Technical Univ. in Prague (Czech Republic)

\section{OPTICAL DEVICES}

66090L The optical vortex interferometer AD 2006 [6609-20]

J. Masajada, Wroclaw Univ. of Technology (Poland)

$66090 \mathrm{M}$ In vitro dynamic observations in a low-coherence holographic microscope [6609-21]

P. Kolman, H. Janečková, R. Chmelík, Brno Univ. of Technology (Czech Republic); P. Veselý, Charles Univ. and Institute of Molecular Genetics (Czech Republic); L. Lovicar, Z. Foret, Brno Univ. of Technology (Czech Republic)

66090N Compact laser tweezers [6609-22]

M. Šerý, Institute of Scientific Instruments (Czech Republic); Z. Lošták, M. Kalman, Meopta-optika, s.r.o. (Czech Republic); P. Jákl, P. Zemánek, Institute of Scientific Instruments (Czech Republic)

660900 Aluminum laser welding optimization [6609-23]

H. Chmelíčková, Joint Lab. of Optics of Palacký Univ. and Institute of Physics (Czech Republic); V. Halenka, Palacký Univ. (Czech Republic); H. Lapšanská, M. Havelková, Joint Lab. of Optics of Palacký Univ. and Institute of Physics (Czech Republic) 
66090P Chamber with controlled atmosphere for fluorescence measurements in the project AIRFLY [6609-24]

L. Nožka, Joint Lab. of Optics of Palacky Univ. and Institute of Physics (Czech Republic); V. Vacek, M. Doubrava, Czech Technical Univ. (Czech Republic); M. Hrabovský, Joint Lab. of Optics of Palacky Univ. and Institute of Physics

(Czech Republic); J. Řídký, Institute of Physics (Czech Republic); P. Schovánek, M. Palatka, Joint Lab. of Optics of Palacky Univ. and Institute of Physics (Czech Republic); M. Boháěová, Institute of Physics (Czech Republic); M. Pech, D. Mandát, Joint Lab. of Optics of Palacky Univ. and Institute of Physics (Czech Republic)

66090Q Primary length standard adjustment [6609-25]

R. Ševčík, J. Guttenová, Institute of Measurement Science (Slovak Republic)

66090R New three-dimensional configuration of multidirectional phase tomograph [6609-26]

M. Antoš, Brno Univ. of Technology (Czech Republic)

66090S Proposal of the $1 \mathrm{~m}$ laser interferometer modification in the Slovak Institute of Metrology [6609-27]

J. Bartl, Institute of Measurement Science (Slovak Republic); R. Fíra, Slovak Institute of Metrology (Slovak Republic)

66090T Avalanche photodioide as two photon correlation detector [6609-28]

J. Blazej, Czech Technical Univ. in Prague (Czech Republic)

$66090 \mathrm{U}$ Theory of chromatic sensor for topography measurements [6609-29]

A. Mikš, J. Novák, P. Novák, Czech Technical Univ. in Prague (Czech Republic)

$66090 \mathrm{~V}$ Calibration and topographic and profilometric methods using the prism normal measurement [6609-30]

T. Rössler, Palacky Univ. Olomouc (Czech Republic); M. Pochmon, D. Mandát, M. Hrabovský, Joint Lab. of Optics of Palacky Univ. and Institute of Physics

(Czech Republic); J. Matušová, Palacky Univ. Olomouc (Czech Republic)

\section{OPTICAL MEASUREMENTS}

66090W Dispersion measurements of a birefrigent holey fiber using white-light spectral interferometry [6609-31]

D. Ciprian, P. Hlubina, J. Trojková, Technical Univ. Ostrava (Czech Republic)

66090X Dispersive white-light spectral interferometry used to measure thickness of a thin film on a substrate [6609-32]

P. Hlubina, D. Ciprian, J. Luňáček, M. Lesňák, R. Chlebus, Technical Univ.

Ostrava (Czech Republic)

66090Y Small area curvature measurement [6609-33]

J. Hošek, Czech Technical Univ. in Prague (Czech Republic)

$66090 Z$ Moiré deflectometry used for refractive index measurements [6609-34]

J. Keprt, Joint Lab. of Optics of Palacky Univ. and Physical Institute (Czech Republic); L. Bartonēk, Palacky Univ. (Czech Republic) 
660910 Comparative studies of water turbidity on the grounds of a nephelometric method and diffraction effects [6609-35]

J. Kirkiewicz, Maritime Univ. (Poland); B. Pawlak, Univ. of Szczecin (Poland);

B. Bieg, R. Pikuła, P. Treichel, Maritime Univ. (Poland); B. Mikłaszewicz,

J. Mrozek-Lejman, Univ. of Szczecin (Poland)

660911 Investigation of the relations between the dust granularity and pollution concentration [6609-36]

J. Kirkiewicz, J. Chrzanowski, Maritime Univ. (Poland)

660912 The estimation of suspension concentration in the Odra River waters by LALLS method [6609-37]

J. Kirkiewicz, P. Treichel, Maritime Academy (Poland); J. Mrozek-Lejman,

B. Miklaszewicz, Univ. Szczecin (Poland); B. Bieg, Maritime Academy (Poland);

B. Pawlak, Univ. of Szczecin (Poland)

660913 Some factors that affect the surface measurement accuracy of a lowcoherence interference microscope [6609-38]

L. Lovicar, R. Chmelík, J. Komrska, V. Matoušková, P. Kolman, Z. Foret, Brno Univ. of Technology (Czech Republic)

660914 Validation of 3D profilometry using total knee artroplasty samples [6609-39] D. Mandat, Joint Lab. of Optics of Palacký Univ. and Institute of Physics (Czech Republic); T. Rössler, Palacký Univ. (Czech Republic); M. Pech, M. Hrabovsky, L. Nozka, M. Pochmon, Joint Lab. of Optics of Palacký Univ. and Institute of Physics (Czech Republic); J. Gallo, Palacký Univ. (Czech Republic)

660915 Application of Shack-Hartmann wavefront sensor for testing optical systems [6609-40]

J. Novak, P. Novak, A. Miks, Czech Technical Univ. in Prague (Czech Republic)

660916 Spatial coherence profilometry [6609-41]

P. Pavlíček, Joint Lab. of Optics of Palacky Univ. and Institute of Physics (Czech Republic); Z. Duan, M. Takeda, The Univ. of Electro-Communications (Japan)

660917 The estimation of suspension concentration in natural waters by means of selected optical methods [6609-42]

B. Pawlak, Univ. of Szczecin (Poland); J. Kirkiewicz, Maritime Univ. (Poland); J. Mrozek-Lejman, R. Gąsowski, W. Staroń, B. Mikłaszewicz, J. Mielnik, Z. Safaryn, Univ. of Szczecin (Poland)

660918 Shape measurement method of concave mirrors [6609-43] M. Pech, M. Hrabovský, P. Schovánek, D. Mandát, L. Nožka, Joint Lab. of Optics of Palacky Univ. and Institute of Physics (Czech Republic)

660919 Verification of abrasion measurement of juncture implants using Fourier profilometry [6609-44]

M. Pochmon, Joint Lab. of Optics of Palacky Univ. and Institute of Physics (Czech Republic); T. Rössler, Palacky Univ. (Czech Republic); D. Mandát, Joint Lab. of Optics of Palacky Univ. and Institute of Physics (Czech Republic);

J. Gallo, Palacky Univ. (Czech Republic); M. Hrabovský, Joint Lab. of Optics of Palacky Univ. and Institute of Physics (Czech Republic) 
$66091 \mathrm{~A}$ Parallel plate testing using the optical vortex interferometer [6609-45]

A. Popiołek-Masajada, B. Dubik, Wrocław Univ. of Technology (Poland)

$66091 \mathrm{~B}$ Optical analysis of suspended particles in the cerebrospinal fluid obtained by puncture from patients diagnosed with the disorders of cerebrospinal fluid (CSF) circulation [6609-46]

W. Staroń, Univ. of Szczecin (Poland); L. Herbowski, Public Provincial Hospital

Complex in Szczecin (Poland); H. Gurgul, Univ. of Szczecin (Poland)

OPTICAL IMAGING

$66091 \mathrm{C}$ Characteristics of the retinal images of the eye optical systems with implanted intraocular lenses [6609-47]

D. Siedlecki, M. Zając, J. Nowak, Wrocław Univ. of Technology (Poland)

$66091 \mathrm{D}$ Retinal images in the human eye with implanted intraocular lens [6609-48]

M. Zając, D. Siedlecki, J. Nowak, Wrocław Univ. of Technology (Poland)

$66091 \mathrm{E}$ Influence of image doubling on modulation transfer function of optical systems [6609-49]

R. Melich, Z. Melich, Institute of Plasma Physics (Czech Republic)

$66091 \mathrm{~F}$ Influence of small deformation of optical element surfaces on optical system imaging quality [6609-50]

Z. Melich, R. Melich, Institute of Plasma Physics (Czech Republic)

$66091 \mathrm{G}$ Distorsion of ultrashort light pulses in optical systems [6609-51]

A. Miks, J. Novak, Czech Technical Univ. (Czech Republic)

$66091 \mathrm{H}$ Chromatic aberration coefficients [6609-52]

A. Miks, J. Novak, P. Novak, Czech Technical Univ. (Czech Republic)

VARIA

660911 Education kits for fiber optics, optoelectronics, and optical communications [6609-53]

M. Hájek, M. Švrček, MIKROKOM, s.r.o. (Czech Republic)

$66091 \mathrm{~J}$ Coherent-state information concentration and purification in atomic memory [6609-54]

J. Herec, R. Filip, Palacký Univ. (Czech Republic)

$66091 \mathrm{~K}$ Some optical properties of metal in non-local potential theory [6609-55]

J. Chrzanowski, Maritime Univ. (Poland)

$66091 \mathrm{~L}$ Human factor as an important phenomenon for the optical radar station operation [6609-56]

A. Novotny, J. Blazej, Czech Technical Univ. in Prague (Czech Republic) 
$66091 \mathrm{M}$ Preparation of bismuth-doped yttrium iron garnets and their characterization [6609-57]

J. Pigošová, Institute of Measurement Science (Slovak Republic); A. Kiliánová, P. Vojtek, Comenius Univ. (Slovak Republic); M. Kopčok, A. Cigáň, Institute of Measurement Science (Slovak Republic)

$66091 \mathrm{~N}$ Vision screening in school children in Strzelin County [6609-58]

M. Zajac, Wrocław Univ. of Technology (Poland)

Author Index 
Downloaded From: https://www.spiedigitallibrary.org/conference-proceedings-of-spie on 26 Apr 2023

Terms of Use: https://www.spiedigitallibrary.org/terms-of-use 


\title{
Conference Committees
}

\author{
Conference Chair
}

Miroslav Miler, Academy of Sciences (Czech Republic)

Conference Honorary Chair

Miron Gaj, Wrocław University of Technology (Poland)

Conference Vice-Chairs

Jerzy Nowak, Wrocław University of Technology (Poland)

Jan Peřina, Palacky University Olomouc and Academy of Sciences

(Czech Republic)

Anton Štrba, Comenius University (Slovak Republic)

International Scientific Board

Ján Bartl, Slovak Academy of Sciences (Slovak Republic)

Miron Gaj, Wrocław University of Technology (Poland)

Ivan Glesk, Comenius University (Slovak Republic) and Princeton

University (USA)

Petr Hlubina, Technical University Ostrava (Czech Republic)

Miroslav Hrabovský, Academy of Sciences (Czech Rupublic)

Zdenek Hradil, Palacky University Olomouc (Czech Republic)

Romuald Jóżwicki, Warsaw University of Technology (Poland)

Henryk Kasprzak, Wrocław University of Technology (Poland)

Miloš Klíma, Czech Technical University in Prague (Czech Republic)

Jirí Komrska, Brno University of Technology (Czech Republic)

Václav Kopecký, Technical University of Liberec (Czech Republic)

Miroslav Miler, Academy of Sciences (Czech Republic)

Jerzy Nowak, Wrocław University of Technology (Poland)

Jan Peřina, Palacky University Olomouc (Czech Republic) and Academy of Sciences (Czech Republic)

Dagmar Senderáková, Comenius University (Slovak Republic)

Przemyslaw Szlachetka, Adam Mickiewicz University (Poland)

Tomasz Szoplik, Warsaw University (Poland)

Anton Štrba, Comenius University (Slovak Republic)

Miroslav Šulc, Technical University of Liberec (Czech Republic)

František Uherek, Slovak University of Technology (Slovak Republic)

and International Laser Centre (Slovak Republic)

Wacław Urbanczyk, Wrocław University of Technology (Poland)

Marek Zajac, Wrocław University of Technology (Poland) 
Session Chairs

Miroslav Jedlička, Czech and Slovak Society for Photonics

(Czech Republic)

Petr Hlubina, Technical University Ostrava (Czech Republic)

Marek Jasiorski, Wrocław University of Technology (Poland)

Miloslav Dušek, Palacky University Olomouc (Czech Republic)

Dagmar Senderáková, Comenius University (Slovak Republic)

Ivan Glesk, Comenius University (Slovak Republic) and Princeton University (USA)

Wacław Urbanczyk, Wrocław University of Technology (Poland)

Czeslaw Radzewicz, Warsaw University (Poland)

Pavel Zemánek, Academy of Sciences (Czech Republic)

Jan Soubusta, Palacky University Olomouc (Czech Republic)

Miroslav Miler, Academy of Sciences (Czech Republic)

Organizing Committee

Miroslav Jedlička, Czech and Slovak Society for Photonics

(Czech Republic)

Maciej Kucharski, Czech and Slovak Society for Photonics (Czech Republic)

Miloš Klíma, Czech Technical University in Prague (Czech Republic)

Miroslav Miler, Academy of Sciences (Czech Republic)

Dagmar Senderáková, Comenius University (Slovak Republic)

Miroslav Svoboda, Technical University of Liberec (Czech Republic)

Milena Zeithamlová, Agency Action M (Czech Republic) 


\section{Introduction}

The 15 $5^{\text {th }}$ Czech-Polish-Slovak Optical Conference (XV CPS OC) was held 11-15 September 2006 in the Northern Bohemian university town Liberec. It was one of the series of regular meetings of the optical communities of the Czech, Polish and Slovak optical communities. The country where the conference takes place and organizer change every two years. Since the conference in Karpacz in 1996 the events have been known as the Conferences on Wave and Quantum Aspects of Contemporary Optics. The selected papers were published in the SPIE Proceedings.

This last Conference was organized for the first time by a new organizer, The Czech and Slovak Society for Photonics, in cooperation with the Faculty of Mechanical Engineering of the Technical University of Liberec. Until now, the conferences in the Czech lands had been organized by the Department of Optics of Palacky University in Olomouc.

The Conference was devoted to the actual achievements in the field of optics that had been reached in participating countries. Participants had the opportunity to attend 9 invited lectures of a planned 10, which covered a wide field of pure and applied modern optics. Five of them are involved in the Proceedings. During two full days and two half days of the Conference, 35 oral contributions were presented, and 27 posters displayed during one poster session. The structure of participants was as follows: 58 from the Czech Republic, 19 from Poland, and 13 from Slovak Republic. This Proceedings volume includes 58 Conference contributions selected by representatives of the International Program Committee Scientific Board.

Unlike the previous conferences of this series, the most contributions were devoted to the field of wave optics. Problems of unusual optical beams, manipulations with objects using optical fields, optical vortex effects, and other similar tasks were discussed. Optical measurements and devices were also in the scope of the contributions.

Evaluating the scientific level of this $15^{\text {th }}$ Czech-Polish-Slovak Conference the International Scientific Board singled out the presence of mostly young participants and their outstanding scientific contributions. Young people with their older colleagues and supervisors constituted the largest portion of contributors.

Thanks for the success of the conference should be expressed to the Technical University of Liberec and the Organizing Committee, and especially to the Members of the International Scientific Board, invited lecturers, session chairs, and to all the participants. 
The next conferences, the $16^{\text {th }}$ Polish-Slovak-Czech Optical Conference on Wave and Quantum Aspects of Contemporary Optics, will be organized by the Wroclaw University of Technology and held in Poland in 2008. We would like to wish our younger colleagues, who continually replace the older generation, great future success.

Miroslav Miler Dagmar Senderáková Miroslav Hrabovský 


\section{... contrast of one century}

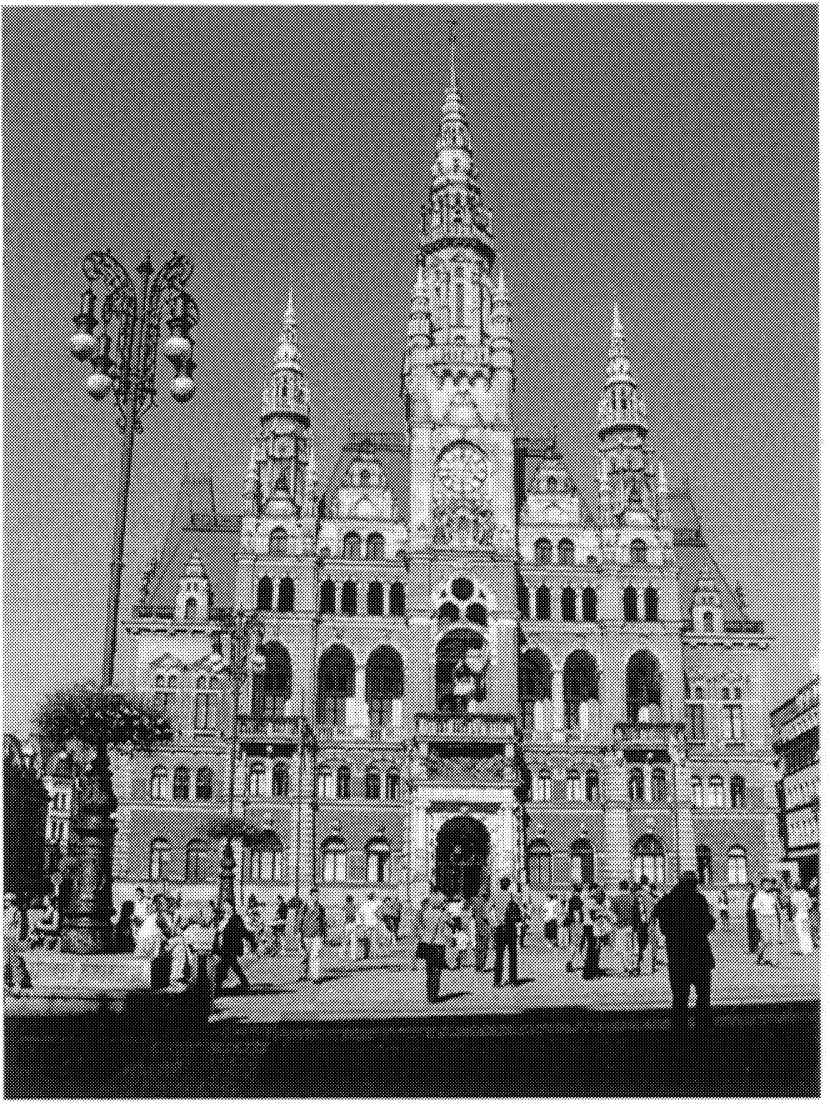

Neoclassical Liberec town hall was designed by the Viennese architect Franz von Neumann and built in 1893. It has been the home of Liberec authority ever since.

Liberec is the administrative, educational, cultural, and economic center of northern Bohemia (western part of the Czech Republic), a true metropolis of the Liberec region and a city of importance of the meeting-point of three regions embodied by the Euroregion Nisa.

Ever since the interwar years Liberec has been known as a center of learning and in 1953 the Liberec College of Mechanical Engineering was founded. In 1960 the Faculty of Textile Engineering was appended. Since political changes in 1989 the College expanded with four new faculties: Education (1990), Economics (1992), Architecture (1994), and Mechatronics and Interdisciplinary Engineering Studies (1995). That year the new University name - Technical University of Liberec, was accepted.

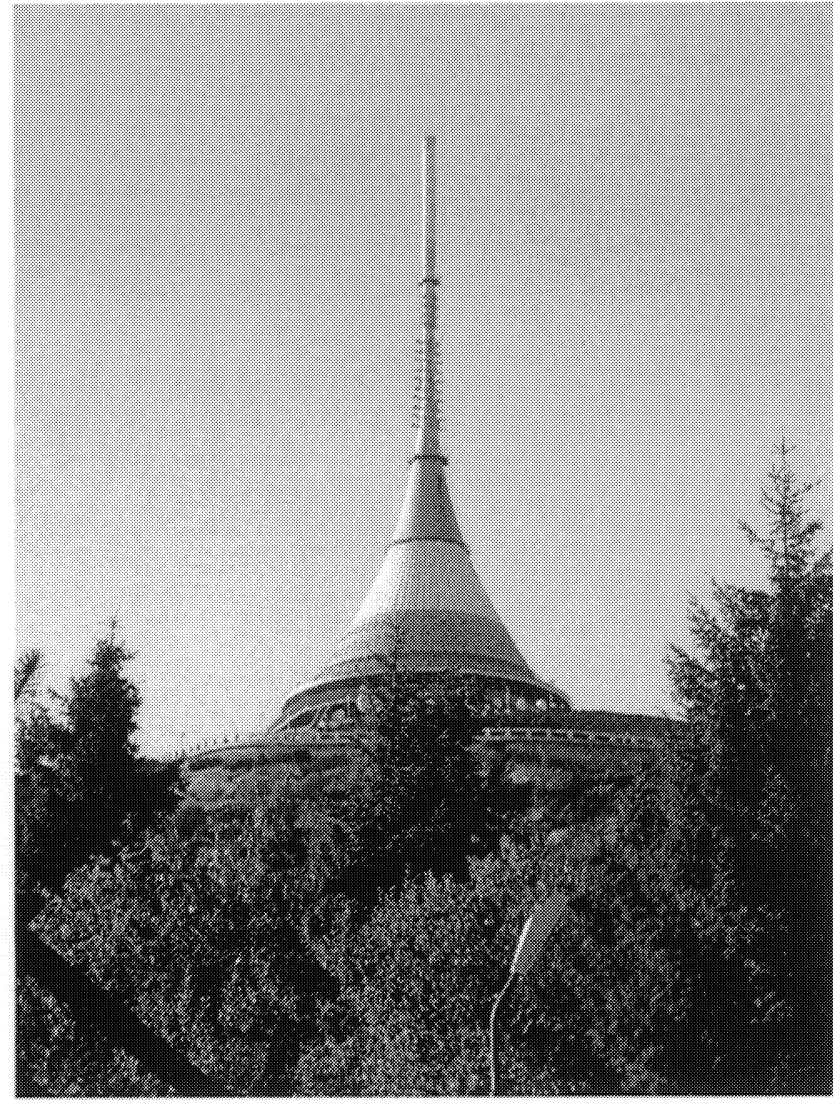

Ještěd Tower is a 100 meter high tower used to transmit television signal. It is built on the top of Ještěd, 1,012-meter high mountain near Liberec. Ještěd Tower is a reinforced concrete construction with a shape of rotational hyperboloid, erected between 1963 and 1968. The shape is intended to resemble a cosmic ship. Karel Hubáček, the architect of the tower, was awarded by the Perret prize. In its lowest sections a hotel and a tower restaurant are located. The tower serves as a dominant attraction in the city and as a place to oversee much of Bohemia and parts of Poland and Germany, too..

The authorities are applying for Ještěd Tower to be included into the UNESCO list of cultural monuments. 


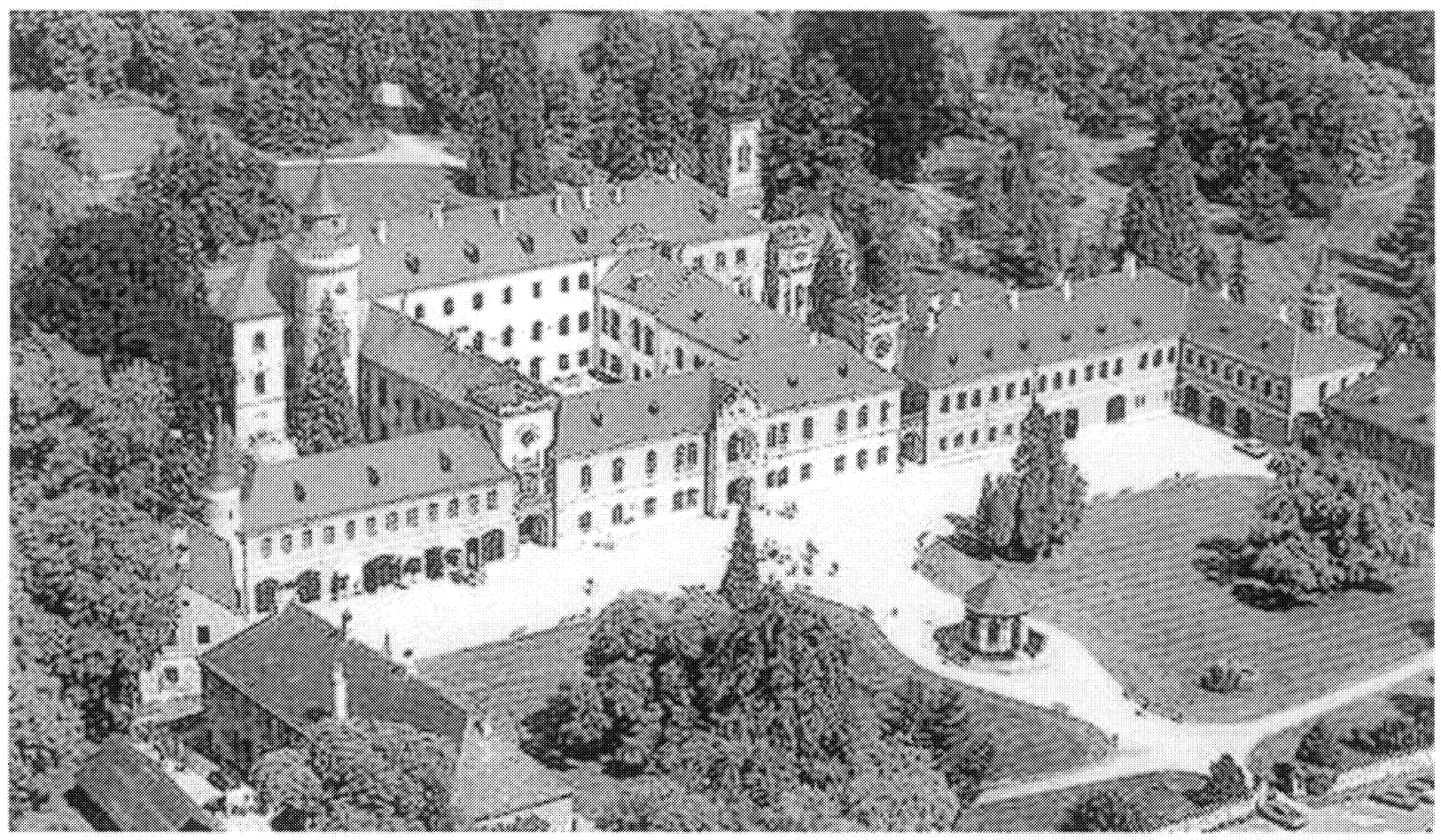

\section{... excursion to Sychrov Chateau}

The Sychrov Chateau, a fine example of the socalled romantic Gothic style, is located not far from Liberec. It owes its current appearance to a French aristocratic family Rohans who settled in Bohemia (1820) after the French Revolution. The owners first had the original small Baroque chateau (built in 1690-1693) converted by K.A. Rohan into an Empire-style structure (1822-1834) and then, around the mid $19^{\text {th }}$ century, remodeled in the neo-Gothic style (1847-1852). Czech artists, including woodcarver Petr Bušek, glass painter Jan Zacharias Quast and sculptor Emmanuel Max, took part in the implementation of the chateau decoration. The splendidly carved Chateau interiors contain more than 200 highly valuable oil paintings, portraits of the ancestors of the ancient French family. Sychrov thus became a unique treasury of French portrait painting. The chateau complex is surrounded by an English park that, at the time of its heyday, served as a model for remarkable arboretums at the Konopiště Chateau and in Prühonice. Sychrov has also been associated with the great Czech composer Antonín Dvořák. He visited it frequently $(1977,1878-$ $1880,1892,1894$, and 1896) at the invitation of Alois Göbel, steward of the Sychrov estate and his friend, to seek recreation and inspiration here (e.g. violin concert A minor, opus 53).

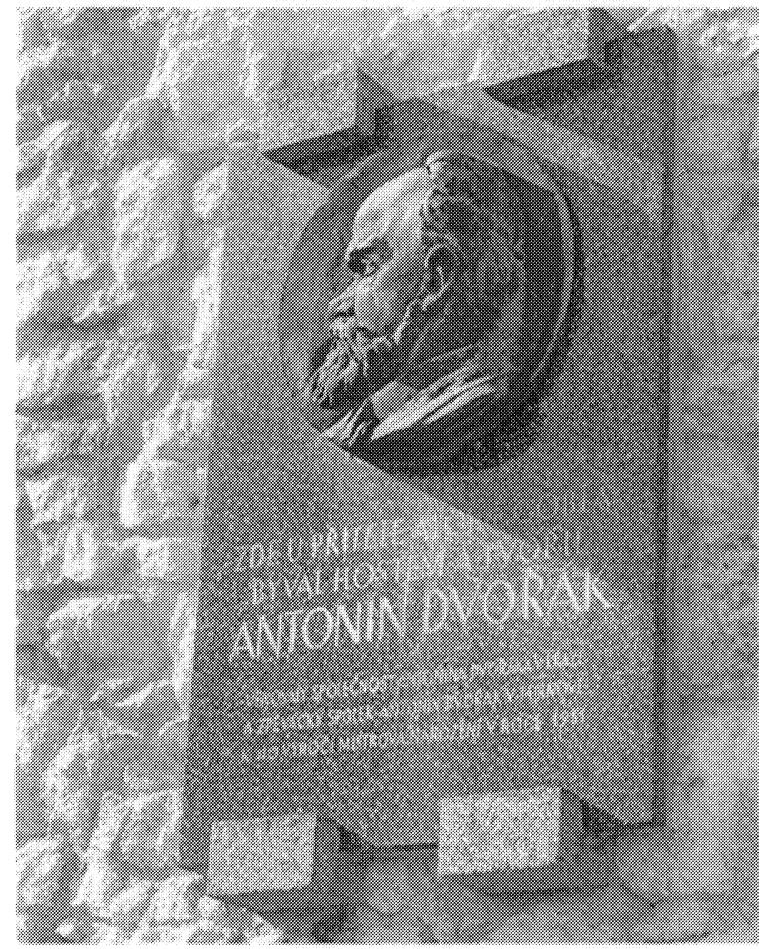

Here, by his friend Alois Gõbel used to be here as a guest and used to compose

ANTONÍN DVOŘÁK.

Dedicated by the Antonín Dvořák Society in Prague and the Antonín Dvořák Choir in Turnov on the $110^{\text {th }}$ artist's birth anniversary in 1951 . 


\section{... from the opening ceremony}



Dr. Miroslav Jedlička, President of the Czech and Slovak Society for Photonics and Chair of the Conference Organizing Committee, addresses the Conference participants on behalf the Society. On the right, Professor Oldîich Jirsák, specialist in the field of nanofibers, who recently won the National Czech Head Award for Nanospider (a functional laboratory model of a nanofiber-forming machine), is paying attention to the opening address. He also welcomed the Conference participants on behalf of the Technical University of Liberec. On the left, another representative of the Technical University of Liberec, Prof. Miroslav Svoboda, who was a Member of the Organizing Committee of the Conference, delegated by the Liberec University. 


\section{... four outstanding personalities of the Conference}
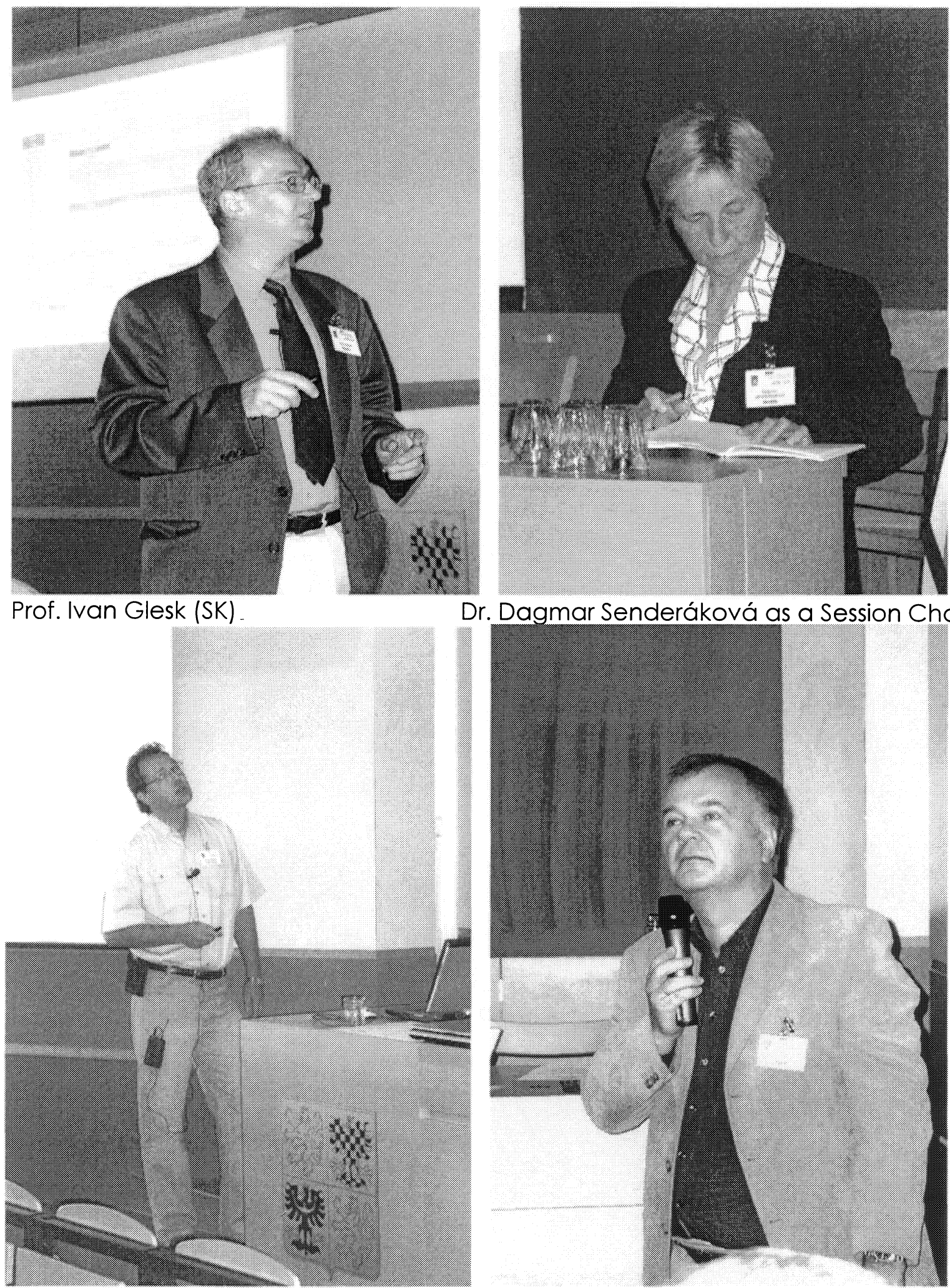

Dr. Dagmar Senderáková as a Session Chair

Prof. Pavel Zemánek (CZ)

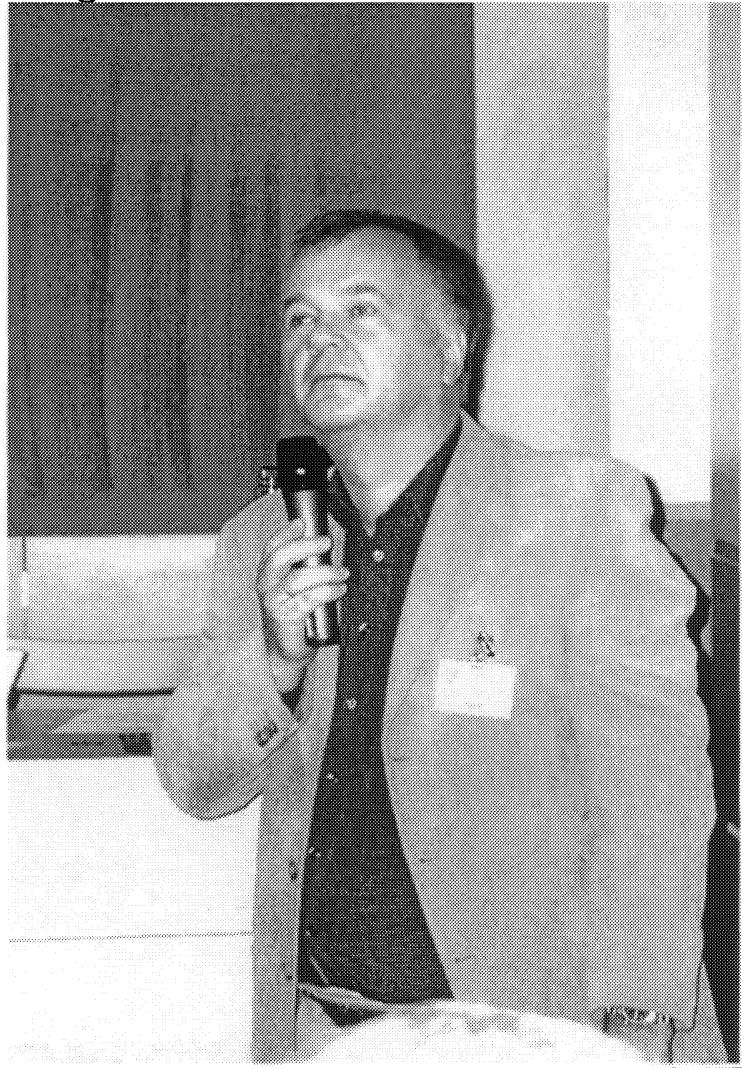

Prof. Waclaw Urbanczyk (PL) 


\section{... young participants during excursion to Liberec town hall}
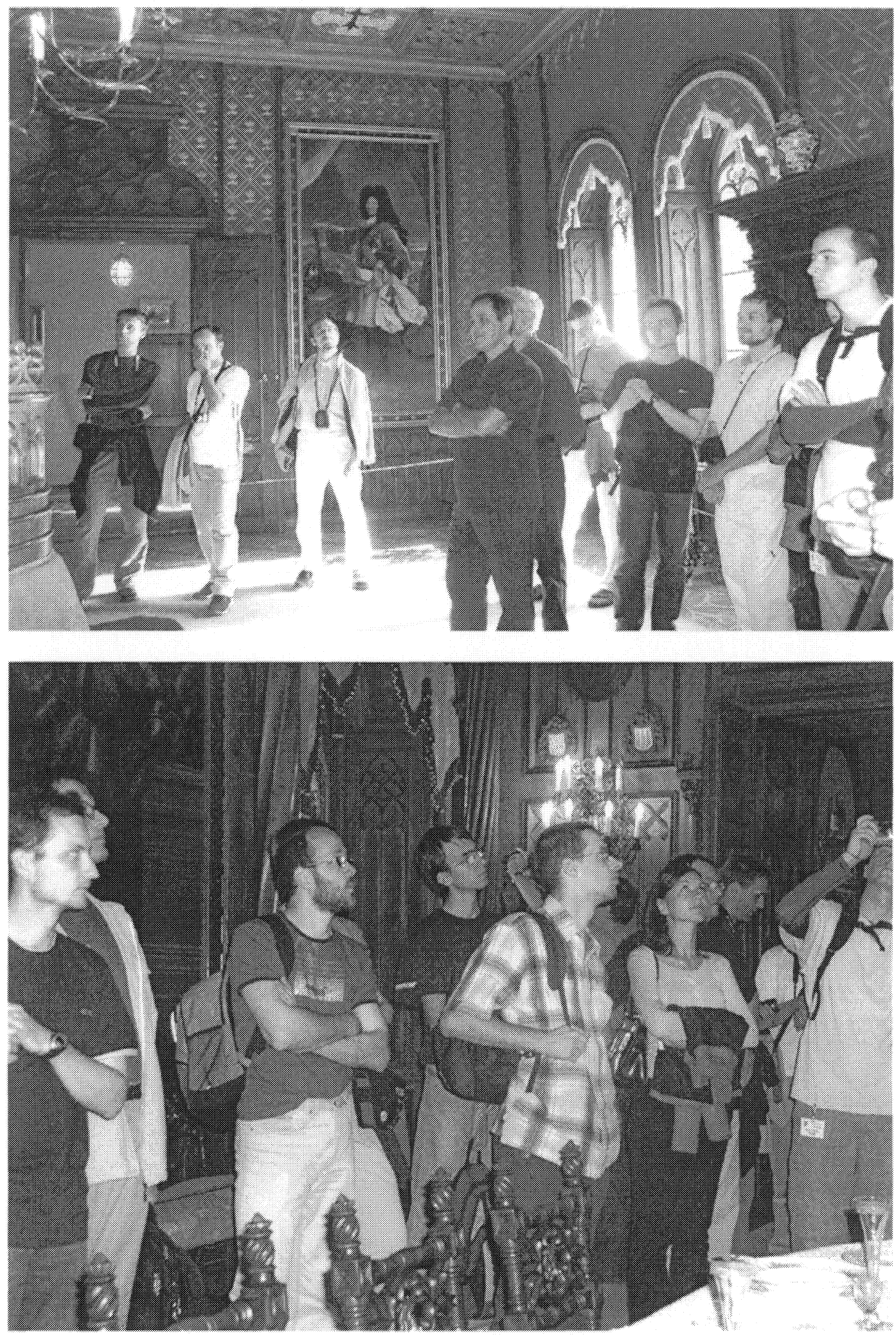


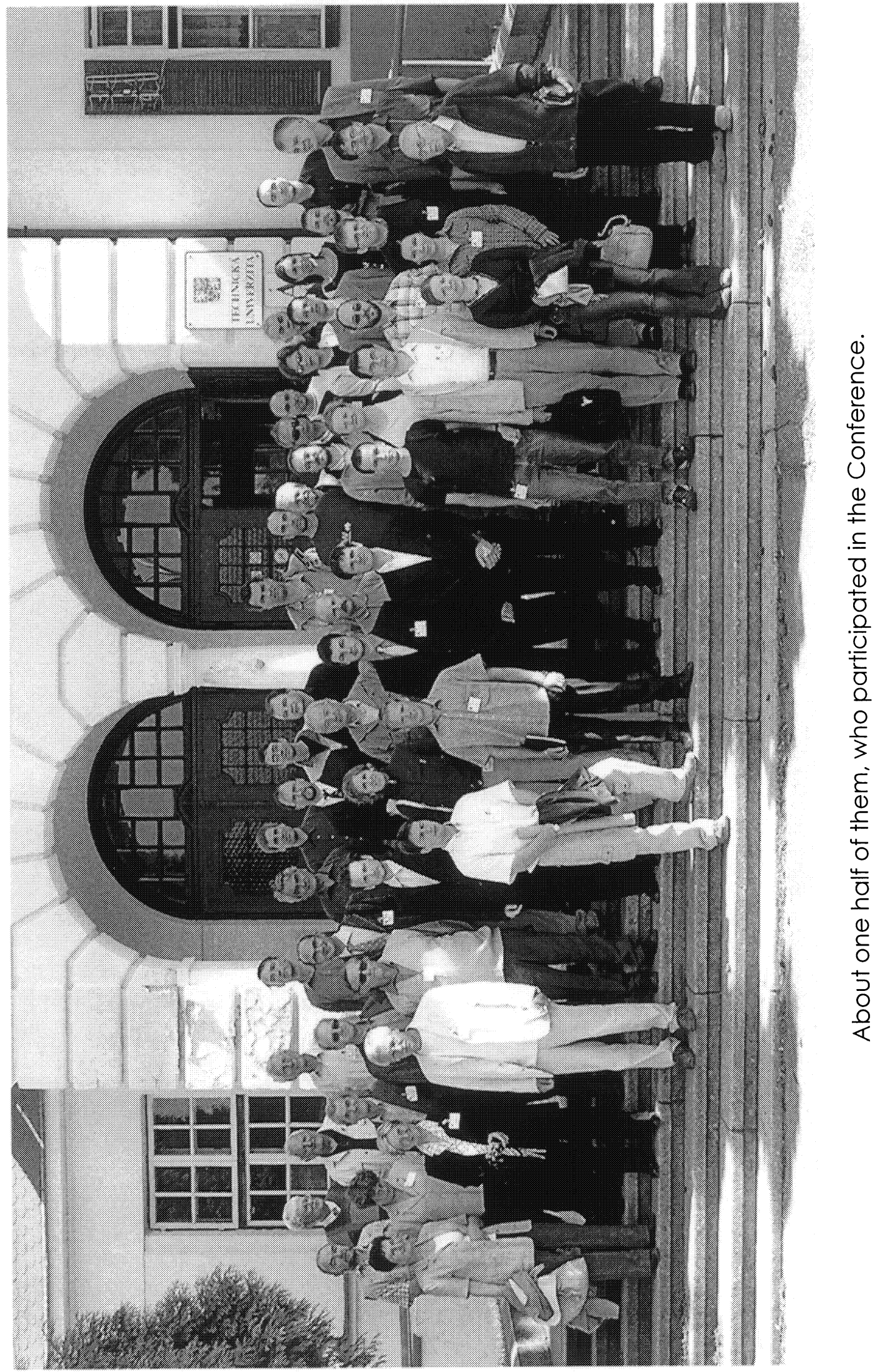

